Article

\title{
Novel Fuzzy Control Energy Management Strategy for Fuel Cell Hybrid Electric Vehicles Considering State of Health
}

\author{
Xiao Hu ${ }^{1, * \mathbb{D}}$, Shikun Liu ${ }^{1}$, Ke Song ${ }^{1,2}$, Yuan Gao ${ }^{1}$ and Tong Zhang ${ }^{1}$ \\ 1 School of Automotive Studies, Tongji University, Shanghai 201804, China; 2031629@tongji.edu.cn (S.L.); \\ ke_song@tongji.edu.cn (K.S.); 14017@tongji.edu.cn (Y.G.); tzhang@tongji.edu.cn (T.Z.) \\ 2 National Fuel Cell Vehicle and Powertrain System Engineering Research Center, Tongji University, \\ Shanghai 201804, China \\ * Correspondence: huxiao@tongii.edu.cn
}

Citation: Hu, X.; Liu, S.; Song, K.; Gao, Y.; Zhang, T. Novel Fuzzy Control Energy Management Strategy for Fuel Cell Hybrid Electric Vehicles Considering State of Health. Energies 2021, 14, 6481. https://doi.org/ $10.3390 /$ en14206481

Academic Editors: Antonino S. Aricò and Pierpaolo Polverino

Received: 30 June 2021

Accepted: 29 September 2021

Published: 10 October 2021

Publisher's Note: MDPI stays neutral with regard to jurisdictional claims in published maps and institutional affiliations.

Copyright: (c) 2021 by the authors. Licensee MDPI, Basel, Switzerland. This article is an open access article distributed under the terms and conditions of the Creative Commons Attribution (CC BY) license (https:// creativecommons.org/licenses/by/ $4.0 /)$.

\begin{abstract}
Due to the low efficiency and high pollution of conventional internal combustion engine vehicles, the fuel cell hybrid electric vehicles are expected to play a key role in the future of clean energy transportation attributed to the long driving range, short hydrogen refueling time and environmental advantages. The development of energy management strategies has an important impact on the economy and durability, but most strategies ignore the aging of fuel cells and the corresponding impact on hydrogen consumption. In this paper, a rule-based fuzzy control strategy is proposed based on the constructed data-driven online estimation model of fuel cell health. Then, a genetic algorithm is used to optimize this fuzzy controller, where the objective function is designed to consider both the economy and durability by combining the hydrogen consumption cost and the degradation cost characterized by the fuel cell health status. Considering that the rule-based strategy is more sensitive to operating conditions, this paper uses an artificial neural network for predictive control. The results are compared with those obtained from the genetic algorithm optimized fuzzy controller and are found to be very similar, where the prediction accuracy is assessed using MAPE, RMSE and 10-fold cross-validation. Experiments show that the developed strategy has a good generalization capability for variable driving cycles.
\end{abstract}

Keywords: fuel cell hybrid electric vehicle; fuzzy control; energy management strategy; state of health; genetic algorithm; neural network

\section{Introduction}

Nowadays, the world is facing problems such as energy shortage, environmental pollution and climate warming caused by non-renewable fossil energy. Automobile energysaving and emission-reduction technologies and stricter emission regulations have alleviated the above problems to a certain extent, but it is difficult for traditional internal combustion engine vehicles to make a qualitative leap [1-3]. The emergence of fuel cell hybrid electric vehicles (FCHEV) has become a practical solution to the upcoming social and environmental problems, which is considered as an important direction for future automobile development [4]. Compared with traditional internal combustion engine vehicles, the biggest difference of FCEVs is that they use fuel cells instead of traditional internal combustion engines as the power source. The electric energy generated by the fuel cells drives the motor and then drives the vehicle. Therefore, FCEVs have the advantages of high energy conversion efficiency, environmental friendliness, long driving range, a fast hydrogenation process and low operating noise [5]. However, in the process of commercialization of fuel cells, the important performance indicators such as safety and durability have not yet reached the level of large-scale promotion [6,7]. Therefore, power sources such as batteries or super capacitors are usually introduced into FCEVs to form the powertrain system [8-10]. Among them, the powertrain system contained the fuel cell, and the battery has been widely used by mass production models, such as Mirai, Clarity, NEXO 
and GLC-F-Cell. Therefore, such configuration of FCEVs is selected as the research object of this article. For powertrain systems with multiple energy sources, energy management strategies (EMSs) considering state of health $(\mathrm{SOH})$ play an important role in delaying the degradation process of fuel cells and improving the durability of the vehicles.

Before formulating an EMS considering $\mathrm{SOH}$, it is necessary to clarify the definition of $\mathrm{SOH}$. Summarizing previous research on fuel cell $\mathrm{SOH}$ monitoring and calculation, $\mathrm{SOH}$ is defined using health indicators, which mainly contain characteristic parameters such as impedance, voltage and power [11]. The electrochemical impedance spectra (EIS) of the fuel cell with different $\mathrm{SOH}$ are obviously different, which are measured under normal water content, electrode flooding and membrane dehydration conditions. Therefore, Kurz et al. [12] and Giner-Sanz et al. [13] selected parameters fitted from EIS as the health indicators for fuel cell $\mathrm{SOH}$ monitoring. However, the operation state of the fuel cell depends on the load, which can hardly meet the approximate stable condition required for EIS test. Especially when using the frequency domain method to measure low-frequency signals, the long test time leads to the reduction of the system stability and the inaccuracy of the test data. Therefore, some researchers such as Meng et al. [14] and $\mathrm{Li}$ et al. [15] chose the voltage drop as the health factor, which is greatly affected by fuel cell degradation. In this article, $\mathrm{SOH}$ of a fuel cell is defined as the ratio of the output voltage drop to the maximum allowable voltage drop. Since the measurement of the output voltage needs to be carried out under the same current density, this definition cannot be applied online in real time to estimate $\mathrm{SOH}$. In order to solve this problem, Yue et al. [16] fitted an empirical formula for fuel cell voltage degradation, but this formula can only predict $\mathrm{SOH}$ online under a fixed current. Wang et al. [17] proposed another $\mathrm{SOH}$ definition method, which integrated the geometric characteristics extracted from the EIS and polarization curves to calculate the Mahalanobis distance between the current state and the initial state to characterize $\mathrm{SOH}$. Although the accuracy of these methods is relatively high, these methods are still limited to offline measurement. The behavior of FCEVs is largely dependent on the environment and driving cycles, whose parameters change accordingly. Because offline models cannot track system changes in real time, online prediction is particularly important. In order to achieve online prediction, a data-driven prediction model is a good option [18]. This method extracts the law of change by analyzing a large amount of experimental data and does not require a comprehensive understanding of the system. In summary, this article constructs an empirical model of fuel cell output power degradation based on experimental data to estimate the $\mathrm{SOH}$ and establish the EMS. The data is based on the power degradation curve fitted from the fuel cell degradation test.

The energy management strategies of FCHEVs so far can mainly be categorized into rule-based and optimization-based algorithms [19]. Rule-based EMS includes thermostat strategy [20], power follower strategy [21], frequency division strategy [22], fuzzy logic control theory [4,23], or hybrid strategy [24,25]. Because the distribution of power demand is managed by several prearranged rules which are based on existing experiment results or research experiences, prior information about a predefined drive cycle is not needed. Among them, fuzzy control theory can add multiple inputs to solve the multi-objective problem through appropriate rules [26,27]. However, the optimality of power distribution cannot be guaranteed under different driving conditions due to a lack of road information. On the contrary, optimization-based strategies transform the aim of energy management into an optimal solution for a globally optimized problem, which include linear programming [28], dynamic programming [29], Pontryagin's minimum principle (PMP) [30,31], equivalent consumption minimization strategy [21,32] and genetic algorithm [31,33]. Genetic algorithm $[34,35]$ is often used in parameter optimization of rule-based strategies to obtain approximate optimal solutions. Ahmadi et al. [35] proposed a fuzzy controller optimized by genetic algorithm for a FCHEV using fuel cell, battery and UC composition. When driving conditions change in actual usage, the optimal parameters obtained by offline optimization are not suitable under different driving cycles. In order to solve this problem, Ryu et al. [36] established a fuzzy controller and used genetic algorithm 
for optimization. Combined with adaptive membership functions based on a stochastic method, this controller ensured the optimal performance under different driving cycles. In addition, owing to the strong learning and adaptive capabilities of neural networks, it has been widely used in the field of predictive control [37]. Therefore, as shown in the research of $[38,39]$, the neural network can be used to predict the driving conditions of the vehicle, and the fuzzy controller parameters under different operating conditions can be selected according to the prediction results to achieve the approximate optimal energy management strategy under unknown operating conditions. When establishing an optimized EMS, more than just fuel economy needs to be considered. In fact, as the use time increases, due to different control strategies, the performance of the fuel cell will be degraded to varying degrees, and finally the durability of the fuel cell will be different [40]. Therefore, using genetic algorithm to optimize the parameters of the fuzzy controller, an EMS that considers the health state of the fuel cell is proposed and then applied for predictive control based on the neural network

The research done so far has added the $\mathrm{SOH}$ into energy management strategies as an influencing factor. In the rule-based EMS, a hierarchical control strategy was proposed in the research of Marx et al. [41]. This strategy reduced degradation by starting as few fuel cells as possible using the state machine method, and reduced fuel consumption by operating as efficiently as possible. Because these rules were designed based on the human expertise, the optimality has not yet been discussed. Considering the $\mathrm{SOH}$ of the fuel cell, Faivre et al. [7] designed a fuzzy controller, which took $\mathrm{SOH}$ and state of charge (SOC) as input, and the reference current of the fuel cell as output. When degradation or failure occurred, the fuel cell operated at its high efficiency point while maintaining the battery's SOC. However, the author has not made a comparative analysis of the hydrogen consumption and durability before and after considering the fuel cell $\mathrm{SOH}$. In the optimization-based EMS, Martel et al. [42] formulated a cost function that considered battery degradation, hydrogen consumption, and charging fees to realize the power allocation in the dynamic programming algorithm. However, this article did not consider the impact of fuel cell degradation and did not conduct health management on fuel cells. Besides this, the dynamic programming algorithm is computationally intensive and sensitive to the driving cycle. In order to prolong the lifetime of the fuel cell, Liu et al. [43] solved the problem of minimizing fuel consumption through PMP optimal control under the constraints of battery SOC and current. This instantaneous optimization strategy aims to minimize the cost function in the current control step, which cannot achieve global optimization. In addition, wavelet transform [44] has also been adopted into EMSs that consider fuel cell life protection. However, since this method requires the driving cycles of the vehicle in advance, its application is limited. To conclude, this article proposes a fuzzy controller based on genetic algorithm to realize global optimization, which can balance the economy and durability. Considering the problem that the rule-based EMS cannot be optimal in real time under different driving cycles, back propagation neural network (BPNN) is adopted to predict the fuel cell output power, which uses the results of the offline optimization of the genetic algorithm under multiple driving conditions as the training data set.

The remainder of this paper is organized as follows. In Section 2, the relevant parameters of the fuel cell vehicle are introduced, and the simulation model of the powertrain system and its key components is completed. Considering the fuel cell SOH, Section 3 proposes an energy management strategy, which uses the genetic algorithm to optimize the fuzzy controller, in order to achieve the optimal state of health and equivalent hydrogen consumption of the fuel cell. In addition, the neural network $(\mathrm{NN})$ is used for predictive control to meet the needs of optimal control under different driving conditions. Compared with other strategies, simulation results under different driving cycles are analyzed in terms of durability and economy in Section 4 . Section 5 provides concluding remarks and proposes future work. 


\section{Fuel Cell Hybrid Electric Vehicle Model}

As shown in Figure 1, here is the fuel cell electric vehicle powertrain system of this study, consisting of the main energy source fuel cell, DC/DC converter, auxiliary energy source battery, drive motor and gearbox. The role of the hydrogen storage tank is to provide fuel for the fuel cell. A DC/DC is connected in series at the rear end of the fuel cell system to maintain the fuel cell system output voltage as stable and consistent with the bus voltage. In this article, the fuel cell and the battery are used as the two energy sources of the powertrain, which supply energy to the motor together. Then, the torque output from the motor directly drives the vehicle. Among them, the fuel cell is the main energy source, and the battery improves the overall efficiency of the system. When the demand power is low, the battery supplies power to the motor to avoid the fuel cell working in the low efficiency range. When the demand power exceeds the maximum power of the fuel cell, the battery supplements the remaining power. In addition, due to the irreversibility of fuel cell energy conversion, the battery can recover braking energy for charging.

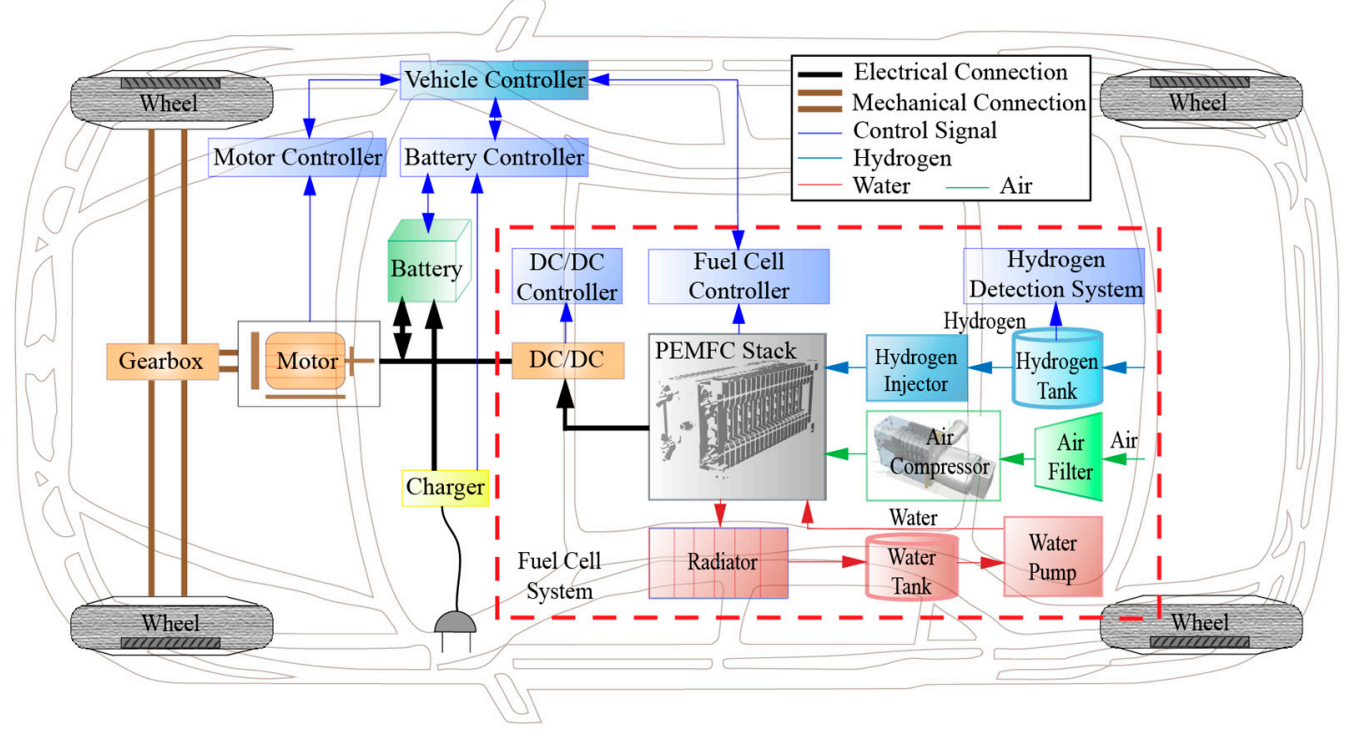

Figure 1. The powertrain system topology of the fuel cell electric vehicle.

\subsection{Vehicle Model}

The key parameters of the FCEV in this article are shown in Table 1. The vehicle model is established mainly based on the longitudinal dynamics of the vehicle [45]. The vehicle needs to overcome rolling resistance $F_{f}$, wind resistance $F_{w}$, acceleration resistance $F_{j}$ and gradient resistance $F_{i}$ during operation. Therefore, the traction force $\sum F$ in this model is calculated as follows:

$$
\left\{\begin{array}{l}
\sum F=F_{f}+F_{w}+F_{i}+F_{j} \\
F_{f}=m g f \cos \alpha \\
F_{w}=\frac{C_{D} A u^{2}}{21.15} \\
F_{i}=m g f \sin \alpha \\
F_{j}=\delta m \frac{d u}{d t} \\
P_{r e q}=\frac{u}{3600 \eta_{T}} \sum F
\end{array}\right.
$$

where $m$ is the mass of the vehicle; $g$ is the acceleration of gravity; $f$ is the coefficient of rolling resistance; $\alpha$ is the slope; $C_{D}$ is the coefficient of air resistance; $\mathrm{A}$ is the front area; $\mathrm{u}$ is the vehicle speed; $\delta$ is the correction coefficient of rotating mass; and $\eta_{T}$ is the efficiency of the transmission system. By calculating the driving resistance, the required power of the powertrain system can be obtained. The vehicle model calculates the deviation between the required speed determined by the driving cycle and the actual speed of the vehicle, which is used as an input to calculate and output the required power of the FCEV. 
Table 1. Vehicle specification.

\begin{tabular}{ccc}
\hline Characteristic & Unit & Value \\
\hline Vehicle gross weight & $\mathrm{kg}$ & 1930 \\
Front area & $\mathrm{m}^{2}$ & 2 \\
Coefficient of rolling resistance & - & 0.012 \\
Coefficient of air resistance & - & 0.33 \\
Battery peak power & $\mathrm{kW}$ & 70 \\
Battery nominal capacity & $\mathrm{Ah}$ & 8 \\
Fuel cell peak power & $\mathrm{kW}$ & 45 \\
Effective area of cell & $\mathrm{cm}^{2}$ & 270 \\
Hydrogen bottle pressure & $\mathrm{MPa}$ & 35 \\
Weight of hydrogen storage & $\mathrm{kg}$ & 3.6 \\
Motor rated/peak power & $\mathrm{kW}$ & $48 / 110$ \\
Motor rated/peak speed & $\mathrm{rpm}$ & $4600 / 11,500$ \\
Motor maximal torque & $\mathrm{Nm}$ & 230 \\
Motor rated voltage & $\mathrm{V}$ & 375 \\
Motor voltage & $\mathrm{V}$ & $335-410$ \\
DC/DC efficiency & - & 0.98 \\
\hline
\end{tabular}

\subsection{Fuel Cell Stack Model}

As long as the continuous supply of the hydrogen is ensured, the fuel cell, as the power source, can continuously convert the chemical energy of the hydrogen into the electrical energy for the powertrain. The combustion reaction of the hydrogen is spatially decomposed into two semi-chemical reactions, and the resulting electrons flow out through an external circuit to drive the load. The efficiency curve of the fuel cell system (FCS) in this article is shown in Figure 2, with a rated output power of $40 \mathrm{~kW}$.

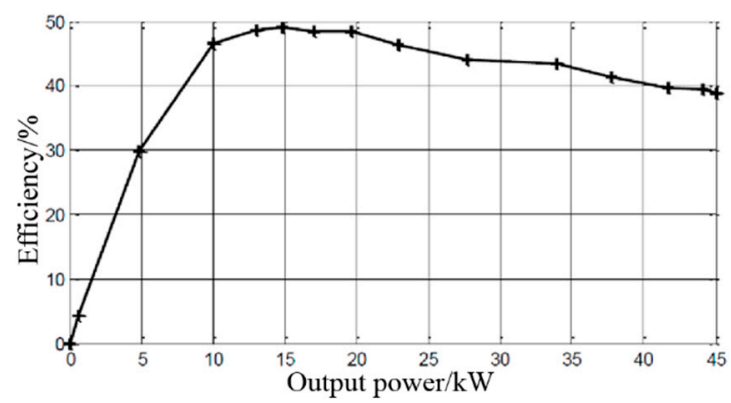

Figure 2. The efficiency curve of the fuel cell system.

It can be seen from Figure 2 that the efficiency of the FCS is closely related to the net output power of the fuel cell. As the output power increases, the efficiency of the FCS increases rapidly in the low power range $(0-5 \mathrm{~kW})$. After the maximum value (49\%) at around $15 \mathrm{~kW}$, the efficiency gradually decreases, and the decreasing speed is much smaller than the increasing speed. This figure provides ideas for the design of EMSs. While keeping the static operating point of the fuel cell in the high efficiency range, EMS should try to avoid the fuel cell working in the low efficiency range.

The hydrogen consumption of the fuel cell $m_{1}$ is calculated by the power of the fuel cell $P_{f_{c}}$ and the corresponding efficiency $\eta_{f_{c}}\left(P_{f_{c}}\right)$, as shown in Equation (3), which was proposed by our research team in the previous work [45]. In this equation, $M_{\mathrm{H}_{2}}$ is the molar mass of hydrogen; $I_{f c}$ is the fuel cell stack current; $n$ is the number of the fuel cells; $F$ is the Faraday constant; and $E_{\mathrm{H}_{2}}$ is the low heating value of the hydrogen.

$$
m_{1}=\int \frac{M_{H_{2}} I_{f_{c}} n}{2 F} d t=\frac{1}{E_{H_{2}}} \int \frac{P_{f c}}{\eta_{f_{c}}\left(P_{f_{c}}\right)} d t
$$




\subsection{Battery Model}

The $\mathrm{LiMn}_{2} \mathrm{O}_{4}$-based lithium-ion battery used in this article is composed of two parallel battery packs. Each pack contains 96 single cells, in which the minimum and the maximum voltage of a single cell are $2.7 \mathrm{~V}$ and $4.2 \mathrm{~V}$. The rated capacity of the battery pack is $8 \mathrm{Ah}$. As shown in Figure $3 \mathrm{a}$, the open circuit voltage and the charge or discharge resistance of a single cell change with the SOC at $298.15 \mathrm{~K}$. The battery model established in this article only needs to reflect the chemical and electrical characteristics of the battery, so it ignores the influence of the consistency and the temperature on the performance of the battery. Referring to the study of Nejad et al. [46], the mathematical models characterizing batteries mainly include the resistor-capacitor (RC) model, Rint model, Randles' model, the theoretical model based on lead-acid battery, and the battery model based on the neural network. Considering the difficulty of parameter identification and the energy management strategy implementation, the Rint battery model is selected for simplification to characterize the battery's voltage and internal resistance $[47,48]$. The equivalent circuit is shown in Figure $3 b$.

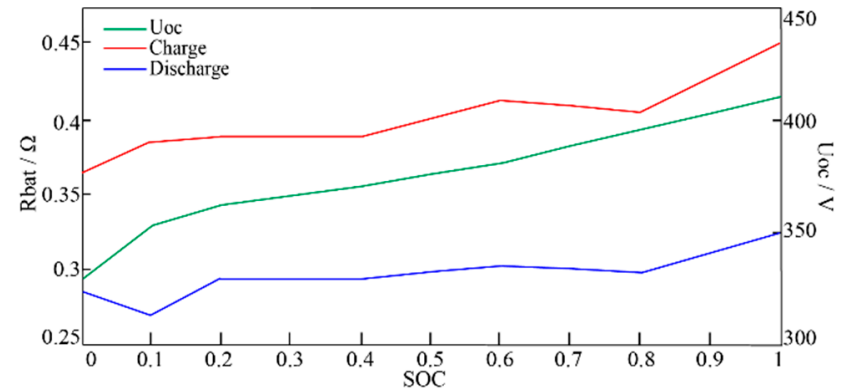

(a)

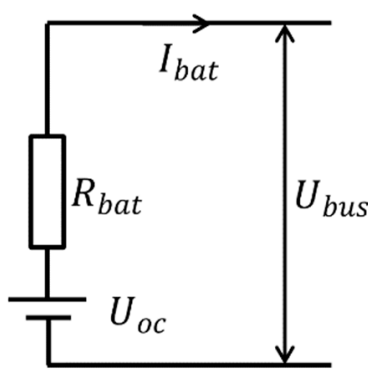

(b)

Figure 3. Battery parameters and the equivalent circuit diagram. (a) Relationship between $R_{b a t}, U_{o c}$ and SOC; (b) Battery Rint model.

The Rint model simplifies the battery into a circuit structure in which a power supply and a resistor are connected in series. Based on this model, as Tribioli et al. mentioned in [49], the relationship between battery output current $I_{b a t}$ and output power $P_{b a t}$ and the relationship between open circuit voltage $U_{o c}$ and internal resistance $R_{b a t}$ are shown in the following Equation (4). $R_{b a t}$ in this equation represents the discharge and charging resistance respectively. Among them, when $P_{b a t}$ is positive, $I_{b a t}$ is also positive, which means the battery is discharging; when $P_{b a t}$ is negative, $I_{b a t}$ is also negative, which means the battery is charging. The calculation method of charge and discharge efficiency is shown in Equation (5). In this article, the ampere-hour integral method [50,51], is used for SOC calculation of the power battery as shown in Equation (6). Among them, $\operatorname{SOC}(0)$ is the initial SOC value, and $C_{\text {cap }}$ represents the battery rated capacity, which is measured under standard conditions. As for $\eta_{C}$, referring to Han et al. [52], it is the battery Columb efficiency, and the value of this variable is 0.98 in the charging state and 1 in the discharging state.

$$
\begin{gathered}
I_{b a t}=\frac{U_{o c}-\sqrt{U_{o c}^{2}-4 R_{b a t} P_{b a t}}}{2 R_{b a t}} \\
\begin{cases}\eta_{d i s}=\frac{U_{O C}-I_{b a t} R_{d i s}}{U_{o c}} & P_{b a t} \geq 0 \\
\eta_{c h g}=\frac{U_{O C}}{U_{O C}-I_{b a t} R_{c h g}} & P_{b a t}<0\end{cases} \\
\operatorname{SOC}(t)=\operatorname{SOC}(0)-\frac{1}{C_{c a p}} \int_{0}^{t} \eta_{C} I_{b a t}(\tau) d \tau
\end{gathered}
$$

In order to calculate the economy of the vehicle, the energy produced by the battery needs to be converted into the equivalent hydrogen consumption of the battery $m_{2}$ according to the average value of the fuel cell efficiency, which is calculated in Equation (7) and 
proposed by $\mathrm{Xu}$ et al. [53]. Among them, $\overline{\eta_{\text {dis }}}$ and $\overline{\eta_{\text {chg }}}$ is the average efficiency of battery discharging and charging; $m_{f c, a v g}$ is the average instantaneous hydrogen consumption of the fuel cell; and $P_{f c, a v g}$ is the average power of the fuel cell.

$$
m_{2}= \begin{cases}\frac{P_{b a t} m_{f c, a v g}}{\eta_{d i s} \eta_{c h r} P_{c c, a v g}} & P_{b a t} \geq 0 \\ \frac{P_{b a t} \eta_{c h g} \eta_{d i s} m_{f c, a v g}}{P_{f c, a v g}} & P_{b a t}<0\end{cases}
$$

\subsection{Electric Motor Model}

The motor used in this article is a permanent magnet synchronous motor, and its efficiency map is shown in Figure 4. In addition to providing the driving force for the vehicle, the motor can also recover braking energy. The model of the motor and its controller should fully consider the operation characteristics and principles of the selected motor. The relationship between motor speed, torque and efficiency is shown in Equation (8), as Song et al. mentioned in [51]. The output torque $T_{M-o u t}$ and required power $P_{M-r e q}$ of the motor can be calculated by Equations (9) and (10), respectively [45]. In these equations, $\eta_{M}$ is the motor efficiency; $n_{M}$ is the motor speed; $T_{M}$ is the motor torque; $P_{\text {out }}$ is the output power of the motor; $\delta_{T}$ is the power torque conversion coefficient; $n_{M-o u t}$ is the actual rotating speed of the motor; $T_{M-r e q}$ is the demand torque; and $\delta_{p}$ is the torque power conversion coefficient.

$$
\begin{gathered}
\eta_{M}=f\left(n_{M}, T_{M}\right) \\
T_{M-\text { out }}=\frac{P_{\text {out }} \delta_{T} \eta_{M}\left(n_{M-o u t}, T_{M-r e q}\right)}{n_{M-o u t}} \\
P_{M-\text { req }}=\frac{T_{M-r e q} \delta_{p} n_{M-o u t}}{\eta_{M}\left(n_{M-o u t}, T_{M-r e q}\right)}
\end{gathered}
$$

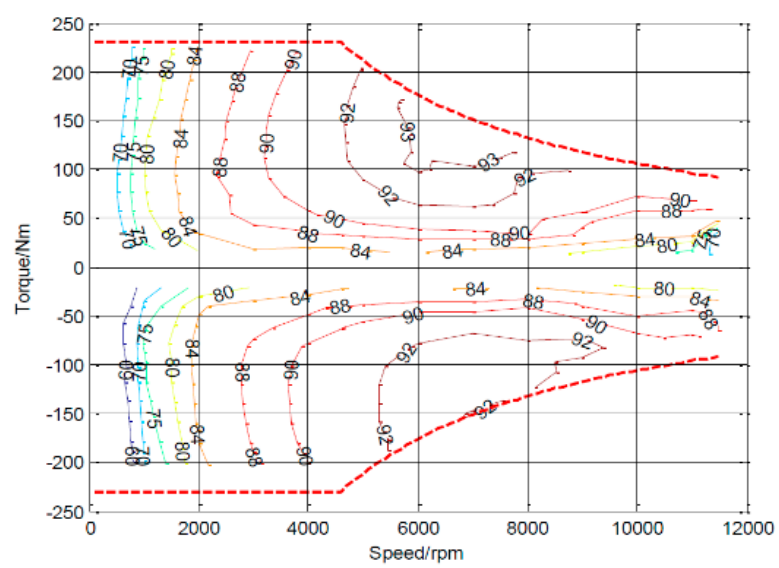

Figure 4. Motor efficiency map.

\section{Fuzzy Control Energy Management Strategy Formulation}

The energy management strategy of the fuel cell powertrain system influences the performance of the fuel cell vehicle deeply. The economy of the powertrain system and the health state of the fuel cell are both important indicators for evaluating the EMS. Therefore, on the basis of the simulation model of the powertrain system, this article formulates an energy management strategy using the fuzzy logic. At the same time, taking economy and $\mathrm{SOH}$ as the optimization targets, parameters of this EMS are optimized using the genetic algorithm (GA). The driving conditions of the vehicle are very complicated, and the demand power of the vehicle changes greatly. The offline optimization control strategy formulated for a certain driving condition cannot be maintained optimal under various conditions. Therefore, the neural network is used to construct a predictive model, so that 
the proposed energy management strategy can be applied online. The framework of the energy management strategy proposed in this paper is shown in Figure 5.

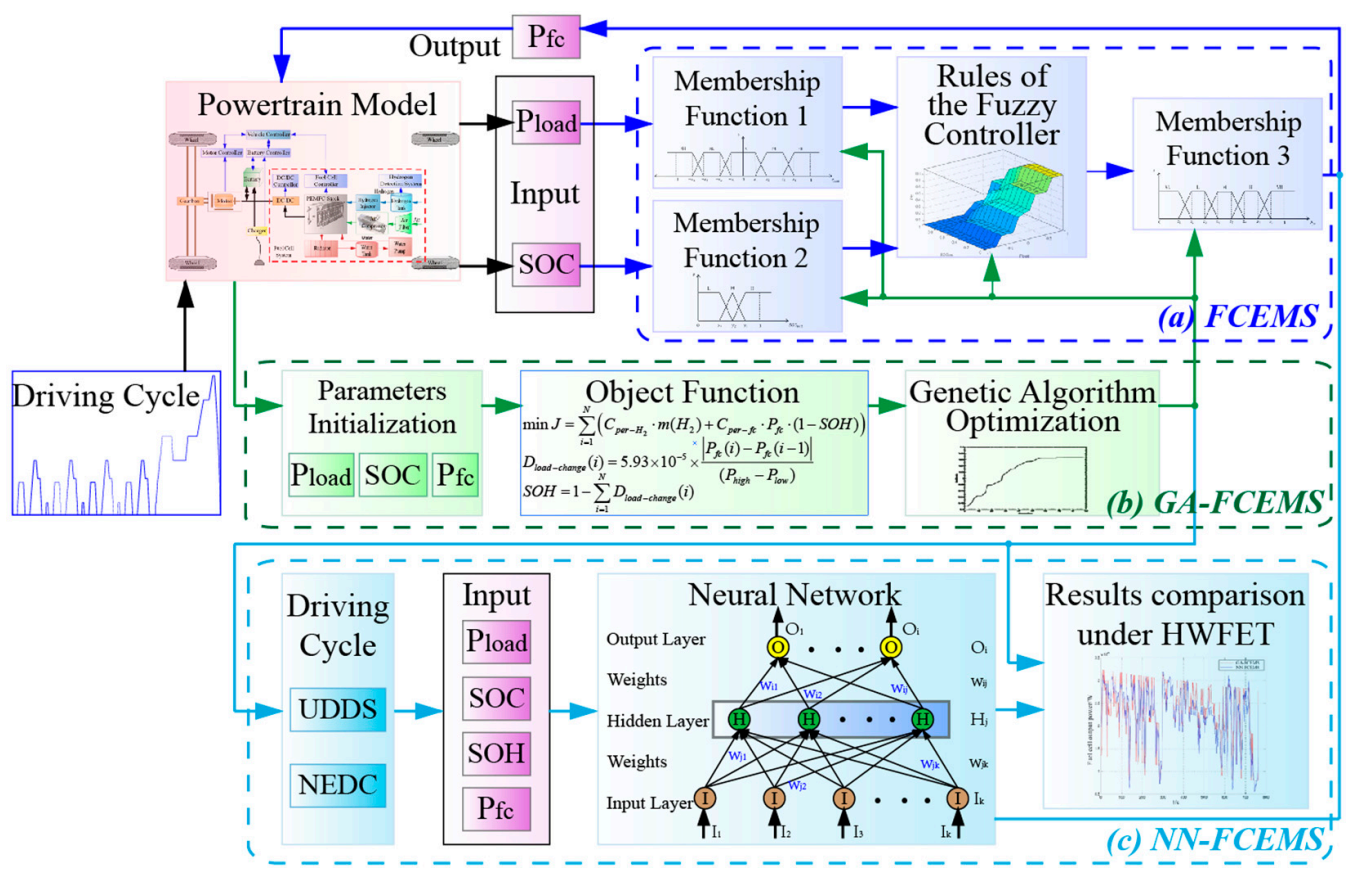

Figure 5. Fuzzy control energy management strategy framework.

\subsection{Rule Establishment of Fuzzy Control Energy Management Strategy}

The FCHEV in this article adopts the dual-input single-output Mamdani fuzzy inference model to realize the fuzzy control in EMS. This fuzzy model does not require an accurate mathematical model of the controlled system and is more adaptable for systems with nonlinear, time-varying, hysteresis and other complex processes [54]. The input of the fuzzy controller is the required power of the motor $P_{\text {load }}$ and the state of charge SOC of the battery pack, and the output is the output power of the fuel cell $P_{f_{c}}$. According to the parameters of each component in the FCEV, the value range of the input and output variables are shown in Equation (11). Then, the quantization factors of parameters $k_{1}, k_{2}$ and $w$ are selected so that the fuzzy domain of input and output variables is normalized to $[0,1]$. The established fuzzy control energy management strategy (FCEMS) can realize the power distribution between the fuel cell and the battery. Considering the actual meaning of each input and output, the designed non-uniformly distributed membership functions are shown in Figure 6. In this figure, it indicates the braking process of the vehicle when $P_{\text {load }}$ is negative, and the output power of the fuel cell $P_{f_{c}}$ cannot be negative.

$$
\begin{cases}P_{\text {load }} \in\left[0,6 \times 10^{4}\right] W & k_{1}=1 /\left(6 \times 10^{4}\right) \\ S O C \in[0,1] & k_{2}=1 \\ P_{f_{c}} \in\left[0,4.5 \times 10^{4}\right] W & w=1 /\left(4.5 \times 10^{4}\right)\end{cases}
$$

Based on the Mamdani fuzzy controller, the fuzzy logic of this FCEMS constructed in this paper is as follows. The power demand of the vehicle during the whole driving process should be ensured. This EMS should optimize the operating range of the PEMFC to improve the powertrain efficiency and thereby improve the economy. The SOC of the battery pack should be maintained near the expected value, so that the energy stored and absorbed by the battery can be fully utilized to extend its lifetime. The output power of the fuel cell should be reduced when $S O C_{b a t}$ is large and $P_{l o a d}$ is small; and $P_{f c}$ should be increased when $S O C_{b a t}$ is small and $P_{\text {load }}$ is large. Based on the above principles, the rules of the fuzzy controller formulated according to the literature and experience are shown in Table 2 [55]. The area center equivalent effect is selected as the clarification method, and the 
three-dimensional relationship between the input and the output for this EMS are shown in Figure 6d.

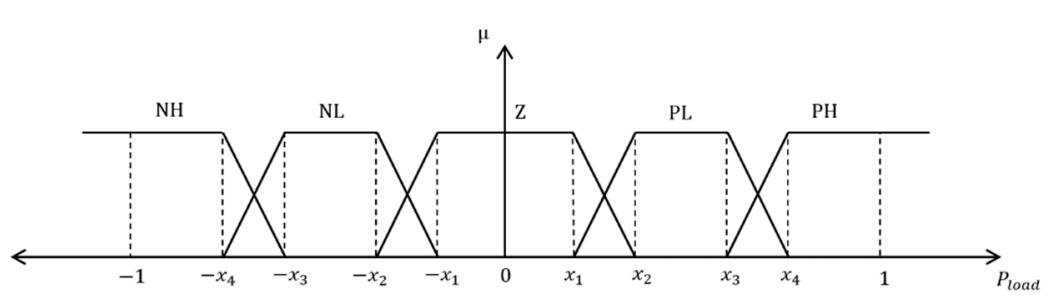

(a)

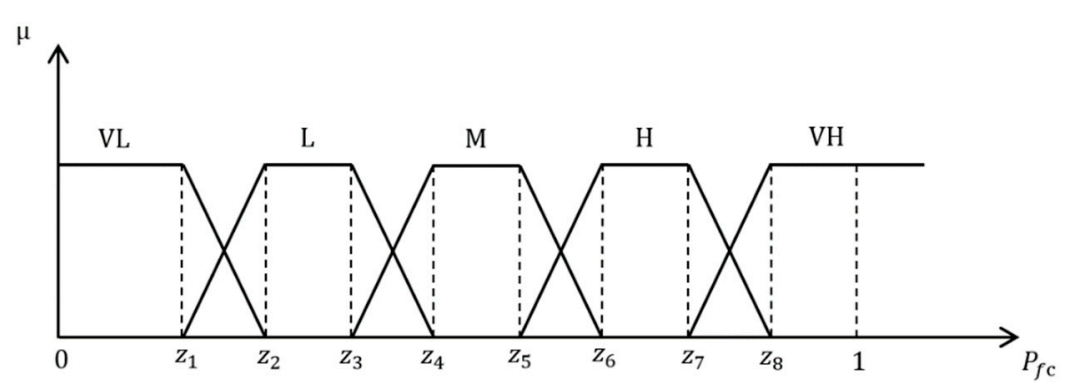

(c)

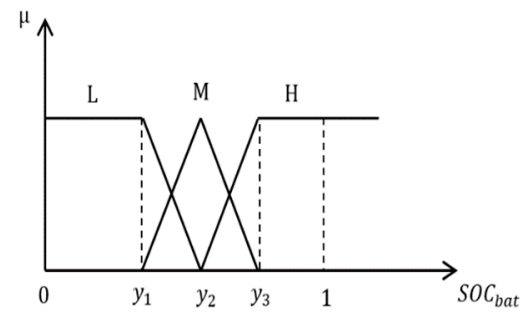

(b)

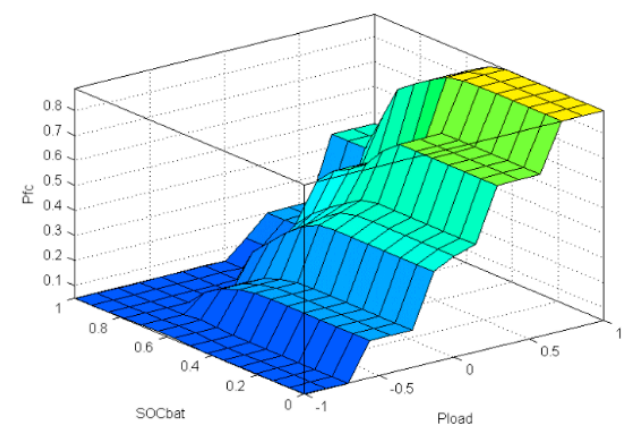

(d)

Figure 6. Membership function in the FCEMS. (a) Membership function of input $P_{\text {load }}$; (b) Membership function of input $S O C_{b a t} ;(\mathbf{c})$ Membership function of output $P_{f c} ;(\mathbf{d})$ The relationship between the input and the output in the FCEMS.

Table 2. Rules of the fuzzy controller in FCEMS.

\begin{tabular}{|c|c|c|c|c|c|c|}
\hline \multicolumn{2}{|c|}{$P_{f_{c}}$} & \multicolumn{5}{|c|}{$P_{\text {load }}$} \\
\hline \multirow{3}{*}{$S O C_{b a t}$} & $\mathrm{~L}$ & VL & $\mathrm{L}$ & $\mathrm{M}$ & $\mathrm{H}$ & $\mathrm{VH}$ \\
\hline & $\mathrm{M}$ & VL & VL & L & $\mathrm{M}$ & $\mathrm{H}$ \\
\hline & $\mathrm{H}$ & VL & VL & VL & $\mathrm{L}$ & $\mathrm{M}$ \\
\hline
\end{tabular}

\subsection{Fuzzy Controller Optimal Design Based on Genetic Algorithm}

The fuzzy control EMS formulated in the previous section can only guarantee the basic power requirements of the vehicle. However, it can be seen from the previous analysis that the driving conditions affect the health state of fuel cells seriously. Therefore, it is necessary to optimize the rules or membership functions of the fuzzy controller so that it can ensure the dynamic performance while achieving the optimization of economy and health. The genetic algorithm is used to optimize the parameters of the membership function in this article. GA is a self-organizing and self-adapting artificial intelligence technology that simulates the evolution process and mechanism of natural organisms, which is based on Darwin's theory of natural selection and Mendel's theory of genetic variation [56]. This method mainly uses genetic operations to implement structural reorganization of individuals with a certain structural form in the population, so as to continuously search for the structural similarity between individuals in the population. Then, building blocks are formed and optimized to gradually approach the optimal solution. Owing to the good global search ability in a complex space, GA has potential parallelism and scalability, which can be combined with various control rules to optimize the controller parameters [57]. Therefore, the effective combination of the GA and the fuzzy control named by GA-FCEMS is used to optimize the fuzzy controller, as shown in Figure $5 b$.

At first, the parameters are initialized. In this article, the initial population $P$ is selected by a uniform random method, and the population size is set to $n=20$; the maximum 
evolutionary generation number is set to $G=100$; the crossover probability is set to $P c=0.6$; and the mutation probability is set to $P m=0.001$. Second, the range of each variable before optimization is defined, as shown in Equation (12). The code length of 15 decision variables to be optimized is 115 bits, which is the number of genes on the chromosome, as shown in Table 3.

$$
\left\{\begin{array}{llll}
x_{1} \in(0,0.2) & x_{2} \in(0.2,0.4) & x_{3} \in(0.4,0.6) & x_{4} \in(0.6,0.8) \\
y_{1} \in(0,0.6) & y_{2} \in(0.6,0.8) & y_{3} \in(0.8,1) & \\
z_{1} \in(0,0.1) & z_{2} \in(0.1,0.2) & z_{3} \in(0.2,0.3) & z_{4} \in(0.3,0.4) \\
z_{5} \in(0.4,0.5) & z_{6} \in(0.5,0.6) & z_{7} \in(0.6,0.7) & z_{8} \in(0.7,0.8)
\end{array}\right.
$$

Table 3. Gene number of decision variables on the chromosome.

\begin{tabular}{cccccccccccccccc}
\hline Variable & $x_{1}$ & $x_{2}$ & $x_{3}$ & $x_{4}$ & $y_{1}$ & $y_{2}$ & $y_{3}$ & $z_{1}$ & $z_{2}$ & $z_{3}$ & $z_{4}$ & $z_{5}$ & $z_{6}$ & $z_{7}$ & $z_{8}$ \\
\hline Gene number /bits & 8 & 8 & 8 & 8 & 10 & 8 & 8 & 7 & 7 & 7 & 7 & 8 & 7 & 7 & 7 \\
\hline
\end{tabular}

In order to find the optimal solution, the optimal goal needs to be formulated. This article selects good individuals through GA to minimize the expected cost in the future. The expected cost is calculated by the cost function $J$, as shown in Equation (13), which includes the cost of fuel consumption and the cost of fuel cell health decline. In order to make the evaluation scales of economy and durability consistent, price weight parameters $\mathrm{C}_{\text {per }-\mathrm{H}_{2}}$ and $\mathrm{C}_{\text {per- } f c}$ are added to Equation (13) to minimize the total operating cost of fuel cell vehicles. The constraints of the system are shown in Equation (14). After repeated iterations of routine operations such as selection, crossover, and mutation, the value of the membership functions of the fuzzy controller when the cost function is the smallest can be screened out. At this time, the durability and economy of the fuel cell meet the optimal requirements.

$$
\begin{gathered}
\min J=\sum_{i=1}^{N}\left(C_{\text {per }-H_{2}} \cdot m\left(H_{2}\right)+C_{p e r-f c} \cdot P_{f c} \cdot(1-S O H)\right) \\
S \cdot t\left\{\begin{array}{c}
P_{f c, \text { min }} \leq P_{f c} \leq P_{f c, \text { max }} \\
P_{b, \text { min }} \leq P_{b} \leq P_{b, \text { max }} \\
S O C_{\min } \leq S O C \leq S O C_{\max }
\end{array}\right.
\end{gathered}
$$

In the cost function, the equivalent hydrogen consumption of a vehicle $m\left(H_{2}\right)$ is the sum of the hydrogen consumption of the fuel cell $m_{1}$ and the equivalent hydrogen consumption of the battery $m_{2}$, which are calculated in Equations (3) and (7) separately. The weighting parameters are selected according to the various costs of fuel cells given in Reference [58], as shown in Table 4 below. The SOH of the fuel cell can be reflected in the degradation of the fuel cell output power. It can be seen from [44] that the decay rate of the fuel cell is different under different operating conditions. Comparing operating conditions such as start-stop cycle, idling operation and high output power, the performance degradation caused by dynamic loading accounted for $41.15 \%$ of the total fuel cell degradation, which can be regarded as the main factor leading to the reduction of fuel cell lifetime. According to the previous study [44], the attenuation of the fuel cell under dynamic loading conditions is shown in Equation (15). After $N$ cycles, the SOH of the PEMFC changes as shown in Equation (16), where $P_{\text {high }}$ is the high-power threshold, and $P_{\text {low }}$ is the low-power thresholds of the fuel cell under idling conditions. Both $P_{h i g h}$ and $P_{\text {low }}$ are determined based on the recommended operating voltage range of the PEMFC.

$$
D_{\text {load-change }}(i)=5.93 \times 10^{-5} \times \frac{\left|P_{f c}(i)-P_{f c}(i-1)\right|}{\left(P_{\text {high }}-P_{\text {low }}\right)}
$$




$$
S O H=1-\sum_{i=1}^{N} D_{\text {load-change }}(i)
$$

Table 4. Cost value of the fuel cells.

\begin{tabular}{cc}
\hline Category & Cost \\
\hline Hydrogen consumption $\left(C_{p e r-H_{2}}\right)$ & $50 ¥ / \mathrm{kg}$ \\
Degradation of the fuel cell $\left(C_{p e r-f c}\right)$ & $4000 ¥ / \mathrm{kW}$ \\
\hline
\end{tabular}

\subsection{Predictive Fuzzy Controller Based on Neural Network}

The effects of the offline optimization control are influenced by driving cycles. For real applications, the driving conditions of the vehicle are always changing, which means it is difficult for the offline control to be convincing. Although the real-time optimization strategy can adjust the power split according to the current state of the vehicle, it demands large calculation. Existing methods usually choose to reduce the computational load at the cost of optimized performance. In addition, its optimality will also be reduced without overall understanding of driving conditions. The neural network algorithm can solve the above problems well. The main calculation amount of the neural network is to use the data set to train it, which can be done offline in advance. Therefore, the training time does not affect the onboard predictive control of the vehicle. In Section 3.2, using the fuzzy controller and genetic algorithm for global optimization, a large data set has been produced to train artificial neural networks. Therefore, a fuel cell output power prediction control based on the neural network (NN-FCEMS) that considers the fuel cell SOH can be established, which takes the demand power, battery SOC, and fuel cell $\mathrm{SOH}$ as three inputs, and the predicted power of the fuel cell as the output. In this article, this fuel cell output power prediction model uses a multi-layer feedforward network and uses a backward propagation algorithm to obtain a set of appropriate weights to make the model output meet the accuracy requirements. The multi-layer feedforward artificial neural network is shown in Figure $5 c$. In Figure $5 c, I_{k}$ is the input layer, which is used to input known measured values. The input layer includes three units, bus demand power $P_{\text {load }}$, battery state of charge $S O C_{b a t}$, and fuel cell $S O H$. The hidden layer $H_{j}$ has three units. The uppermost output layer $O_{i}$ contains one unit that outputs the fuel cell power corresponding to each set of input data. The data set of the results obtained under the 'Urban Dynamometer Driving Schedule' (UDDS) or 'New Europe Driving Cycle' (NEDC) driving cycles in Section 3.2 is used as the learning sample, where $s$ represent 1309 samples. When the original data of the sample $s$ is input into the network, the state of the corresponding output unit is recorded as $O_{i}^{s}(i=1)$, the state of the hidden unit is recorded as $H_{j}^{s}(j=1,2,3)$, and the value of the input unit is $I_{k}^{s}(k=1,2,3)$. Here the subscripts $i, j$, and $k$ correspond to the output layer, the middle layer, and the input layer in turn. Then, a set of appropriate weights $\left\{w_{i j}, \bar{w}_{j k}\right\}$ are selected using the back-propagation algorithm, so that for any set of learning samples with the input of $I_{1}^{s}, I_{2}^{s}, I_{3}^{s}$, the output $O_{1}^{s}$ is the same as the fuel cell output power that was obtained by the fuzzy controller optimized using GA, with the goal of minimum fuel cell performance degradation and hydrogen consumption, or the difference is within the allowable error range to realize the power prediction. Therefore, for any sample under unknown driving conditions, as long as $P_{\text {load }}, S O C_{b a t}$ and $\mathrm{SOH}$ are input to the network, power can be allocated to the fuel cell based on their output. Since this method of power split is the result of learning the algorithm in Section 3.1, it can consider the fuel cell SOH and the hydrogen consumption. Therefore, the neural network model established in this article is trained with 1309 sets of data, and 60 sets of data are tested. The numerical values output of this model is denormalized to obtain the desired prediction results.

\section{Results and Discussion}

On the basis of meeting the dynamic demand, the energy management strategy established in this article also considers the economy of the vehicle and the $\mathrm{SOH}$ of the 
fuel cell. After applying the genetic algorithm to optimize the fuzzy controller for a single driving condition, the neural network is used to predict and control the power split considering the practical application. This section analyzes its feasibility based on the simulation results of the above control algorithm. Simulation conditions are as follows: in all simulation processes, the initial value of battery SOC is set to 0.5 ; the ambient temperature for vehicle operation is $298.15 \mathrm{~K}$.

\subsection{GA-FCEMS Results Analysis under Different Driving Cycles}

This article selects three standard driving cycles of UDDS, NEDC, and 'Highway Fuel Economy Test Cycle' (HWFET) as the vehicle operating conditions. It can be seen from Figure 7 that under the UDDS driving cycle, the objective function of GA gradually converges. Additionally, the optimized fuzzy controller membership function parameters that minimize the objective cost function can be obtained quickly, which are shown in Table 5. The simulation results of the power distribution before and after optimization under UDDS are shown in Figure 8.

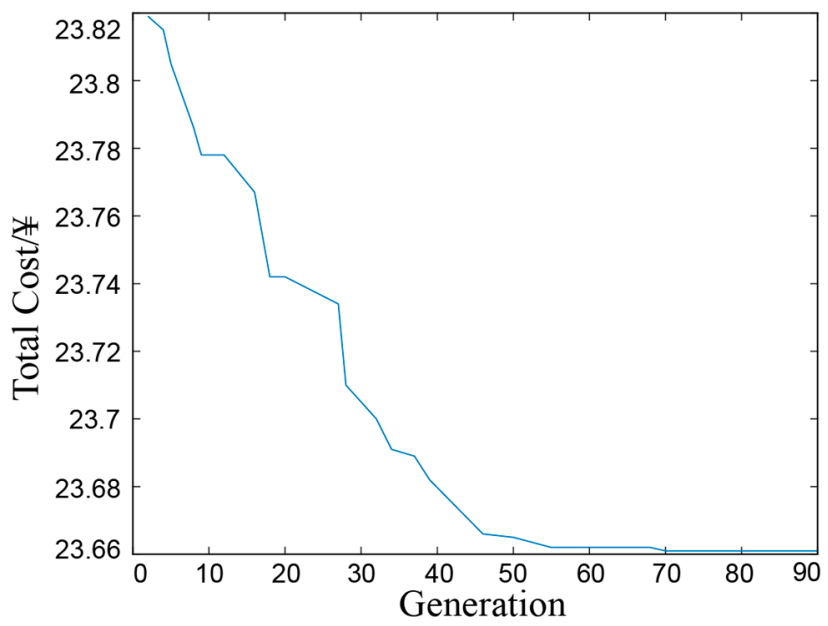

Figure 7. The value of optimal individual objective function under UDDS.

Table 5. Comparison of membership functions between FCEMS and GA-FCEMS.

\begin{tabular}{|c|c|c|c|c|c|c|c|c|c|c|c|c|c|c|c|}
\hline Variable & $x_{1}$ & $x_{2}$ & $x_{3}$ & $x_{4}$ & $y_{1}$ & $y_{2}$ & $y_{3}$ & $z_{1}$ & $z_{2}$ & $z_{3}$ & $z_{4}$ & $z_{5}$ & $z_{6}$ & $z_{7}$ & $z_{8}$ \\
\hline Original & 0.0008 & 0.2329 & 0.4282 & 0.6235 & 0.1296 & 0.6871 & 0.9255 & 0.0654 & 0.1236 & 0.2653 & 0.3433 & 0.5914 & 0.6181 & 0.7244 & 0.8315 \\
\hline Optimized & 0.0706 & 0.3467 & 0.5490 & 0.7890 & 0.5554 & 0.6384 & 0.8251 & 0.0386 & 0.1976 & 0.2087 & 0.3827 & 0.4149 & 0.6661 & 0.7480 & 0.8331 \\
\hline
\end{tabular}

Figure $8 \mathrm{a}, \mathrm{b}$ illustrated the speed of the vehicle and the power on the bus, which are only determined by the driving cycles and the type of vehicles. Comparing Figure $8 c, d$, it can be found that the EMS considering the fuel cell SOH reduces the output power of the fuel cell from 0-40 kW to 0-30 kW. Under the NEDC and HWFET cycles, the simulation results of fuzzy controller with and without genetic algorithm optimization are compared when the initial SOC is 0.5 , as shown in Table 6 . It can be seen that the optimization range of hydrogen consumption and fuel cell degradation has reached more than $7 \%$ under UDDS. The fuzzy controller based on genetic algorithm optimization under NEDC optimizes the cost of hydrogen to $1.1863 \%$, and the cost of fuel cell degradation to $7.9026 \%$, which is an obvious effect. In addition, the total cost of the system is optimized to $11.66 \%$ under HWFET, which further illustrates the rationality of this proposed EMS. 

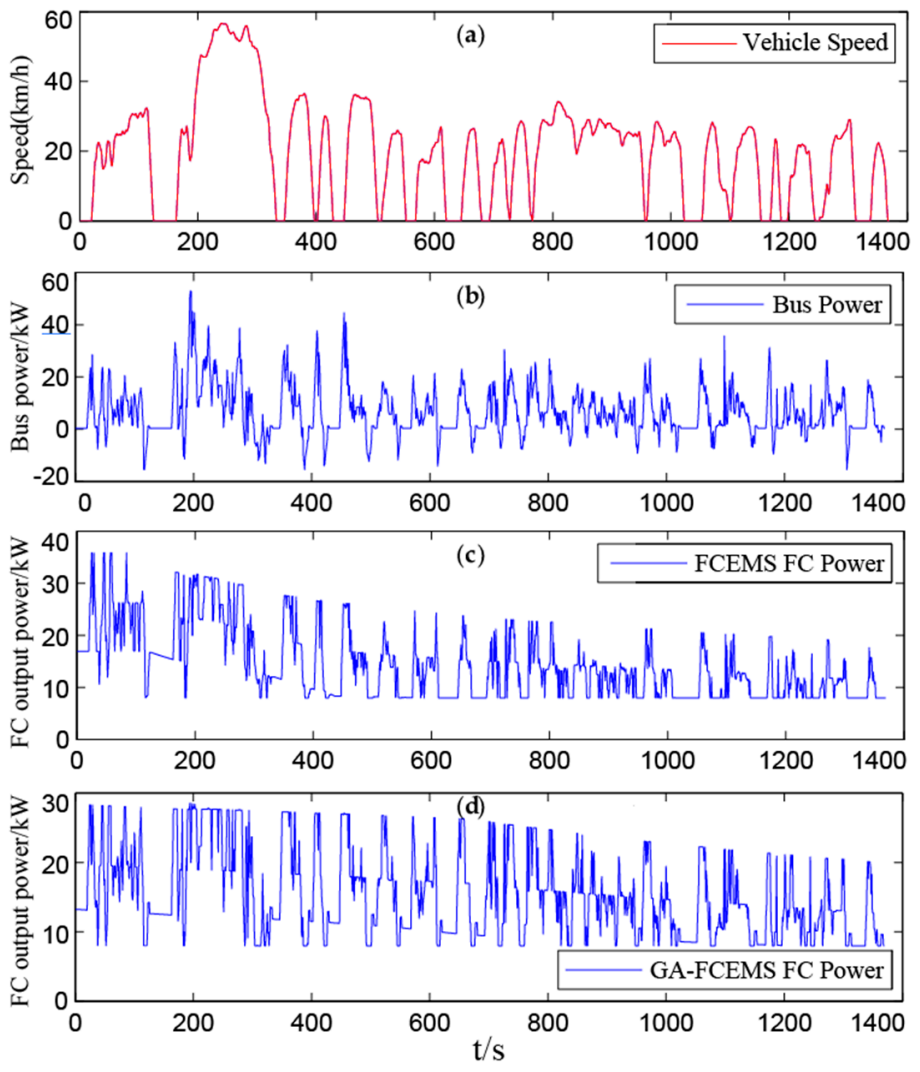

Figure 8. Vehicle speed and power distribution before and after optimization under UDDS. (a) Vehicle speed; (b) Bus power of the powertrain; (c) Fuel cell output power in FCEMS; (d) Fuel cell output power in GA-FCEMS.

Table 6. Results comparison between FCEMS and GA-FCEMS per cycle under UDDS/NEDC/HWFET.

\begin{tabular}{|c|c|c|c|c|c|c|c|c|c|}
\hline \multirow[b]{2}{*}{ Cost/\# } & \multicolumn{3}{|c|}{ UDDS } & \multicolumn{3}{|c|}{ NEDC } & \multicolumn{3}{|c|}{ HWFET } \\
\hline & $\begin{array}{c}\text { GA- } \\
\text { FCEMS }\end{array}$ & FCEMS & Difference & $\begin{array}{c}\text { GA- } \\
\text { FCEMS }\end{array}$ & FCEMS & Difference & $\begin{array}{c}\text { GA- } \\
\text { FCEMS }\end{array}$ & FCEMS & Difference \\
\hline Hydrogen & 18.1629 & 19.4575 & $7.1277 \%$ & 11.2700 & 11. 4037 & $1.1863 \%$ & 14.6782 & 16.7012 & $13.7602 \%$ \\
\hline $\begin{array}{c}\mathrm{FC} \\
\text { degradation }\end{array}$ & 5.4991 & 6.0096 & $9.2833 \%$ & 0.8744 & 0.9435 & $7.9026 \%$ & 3.4796 & 3.5750 & $2.7417 \%$ \\
\hline Total & 23.6620 & 25.4671 & $7.6287 \%$ & 12.1444 & 12.3472 & $1.6699 \%$ & 18.1578 & 20.2762 & $11.6666 \%$ \\
\hline
\end{tabular}

Because the fuel cell power degraded when its $\mathrm{SOH}$ declines, the optimized power split can be obtained using GA optimization, which minimizes the fuel cell SOH loss. It can be seen from Table 7 that the $\mathrm{SOH}$ values after 10,000 cycles under different driving conditions are higher than that without GA optimization. At the same time, the power loss of a fuel cell is closely related to its operating conditions, especially dynamic loading conditions. Therefore, the essence of the optimization algorithm when selecting the membership function parameters for the fuzzy controller is to select the set of parameters which can minimize the fluctuation of the output power of the fuel cell. It can be seen that the control strategy can reduce the equivalent hydrogen consumption cost and degradation cost of the fuel cell while accomplishing the purpose of delaying the decline of $\mathrm{SOH}$, which is consistent with the simulation results shown in Table 6 . And because of this, the output power fluctuation of the fuel cell has also been significantly improved, as shown in Figure 8 . In Table 7, the optimization of the SOH under the NEDC cycle is not as large as that under UDDS and HWFET cycles. This is because the fuel cell demand power fluctuations under the NEDC cycle are relatively small, which provides little space for the optimization. 
Table 7. Results comparison between FCEMS and GA-FCEMS under 10,000 UDDS/NEDC/HWFET cycles.

\begin{tabular}{cccc}
\hline Driving Cycle & SOH in FCEMS & SOH in GA-FCEMS & Difference \\
\hline UDDS & 0.6661 & 0.6945 & $4.2636 \%$ \\
NEDC & 0.9476 & 0.9514 & $0.4010 \%$ \\
HWFET & 0.7792 & 0.8067 & $3.5293 \%$ \\
\hline
\end{tabular}

\subsection{NN-FCEMS Results Analysis under Different Driving Cycles}

In order to verify the cross-generalization ability of the neural network, the predictive control strategy NN-FCEMS is trained under the UDDS and NEDC cycles, and each cycle contains 1309 sets of data. Then, this strategy is tested under the HWFET cycle. Sixty sets of data and eighty-five sets of data under UDDS and NEDC cycles are reserved separately as the test set during NN training. The prediction accuracy of the trained neural network was evaluated, and the comparison between the obtained prediction value and the actual value of the fuel cell output power is shown in Figure 9. As can be seen in this Figure, given the total demand power and the battery SOC, the predicted result is not much different from the actual value, and the change trend is consistent. This indicates that the individual deviations of no more than $1.3 \%$ due to the insufficient training sample set will not have a significant impact on the hydrogen consumption and performance degradation of fuel cell vehicles. In Figure $9 b, d$, the fuel cell output power obtained by NN is very similar to that obtained by GA, which shows no significant or abnormal trend. In order to make the fuel cell operate in the high-efficiency area as much as possible to improve economy, the minimum value of fuel cell output power is set in the fuzzy controller optimized by genetic algorithm, as shown in Equation (14). As shown in Figure 9b, the lowest point of the blue line is lower than the red line, because the soft margin is set, which means the fuel cell power is allowed to be slightly lower than the minimum value $P_{f c, \min }$. Since the continuous output of the fuel cell will cause the battery SOC to accumulate, the soft margin results in no significant charge accumulation or charge exhaustion. At the same time, it reduces the frequency of the startup, shutdown and high-power of the fuel cell, which means the fuel cell $\mathrm{SOH}$ is improved.

The training results of the artificial neural network are tested under the HWFET cycle, and the estimated fuel cell output power is shown in Figure 10. This article uses the root mean square error (RMSE), the mean absolute percentage error (MAPE) and k-fold cross-validation to evaluate the accuracy of the $\mathrm{NN}$ in the fuel cell output power prediction, and these methods have already been applied by Dolatabadi et al. [59], Bobyr et al. [60], Xiong et al. [61] and Hong et al. [62]. The specific calculations for RMSE and MAPE are shown in Equations (17) and (18). In these equations, $P_{G A}$ represents the target output power of the fuel cell obtained by the fuzzy controller optimized using the genetic algorithm; and $P_{N N}$ represents the predicted fuel cell output power using the neural network obtained by the genetic algorithm optimized fuzzy controller. The prediction accuracy assessment using MAPE and RMSE is shown in Table 8 below. As for $k$-fold cross-validation, the data set of the established neural network is divided into $k$ disjoint groups, where $k=10$ in this article. One group is selected as the test data set each time, and the others are the training data sets. The average accuracy is obtained by iterating ten times of k-fold cross-validation. Here, the prediction accuracy of the neural networks under UDDS and NEDC is expressed by the determination coefficient $-R^{2}$, as shown in Table 9. It can be seen that the accuracy of the prediction results is high; that is, the strategy is well adapted to different road conditions. Table 10 summarizes the comparison between the results after GA-FCEMS and NN-FCEMS control for vehicles with different driving conditions when the initial SOC is 0.5. It can be seen that the overall optimization effect is similar. However, NN is better adapted to the NEDC cycle, where the system cost is reduced by about $1.08 \%$ compared to GA. However, the system cost increases by approximately $4.62 \%$ in the HWFET cycle. This can be attributed to the fact that part of the data in the NEDC 
is the training sample data, and the prediction under the HWFET cycle is based entirely on the regular model learned by the NN, which also supports the fact that the larger and richer the training sample data, the higher the accuracy of our prediction will be.

$$
\begin{gathered}
R M S E=\sqrt{\frac{1}{n} \sum_{t=1}^{n}\left(P_{G A}-P_{N N}\right)^{2}} \\
M A P E=\frac{1}{n} \sum_{t=1}^{n}\left|\frac{P_{G A}-P_{N N}}{P_{G A}}\right|
\end{gathered}
$$

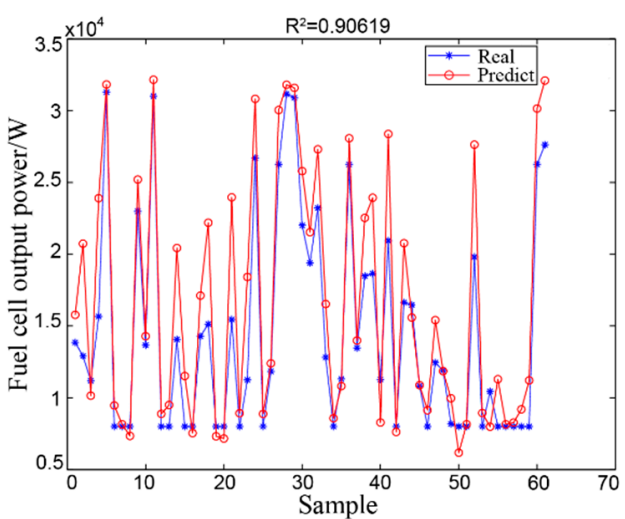

(a)

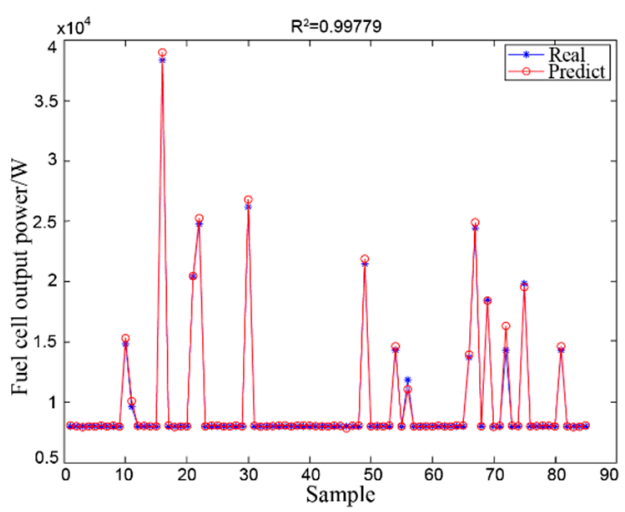

(c)

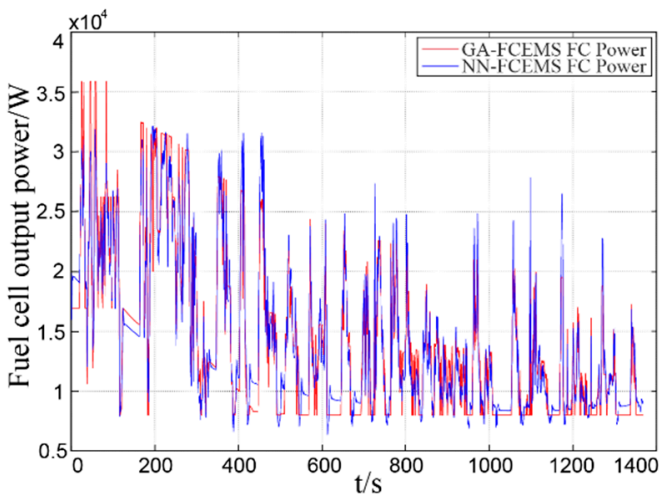

(b)

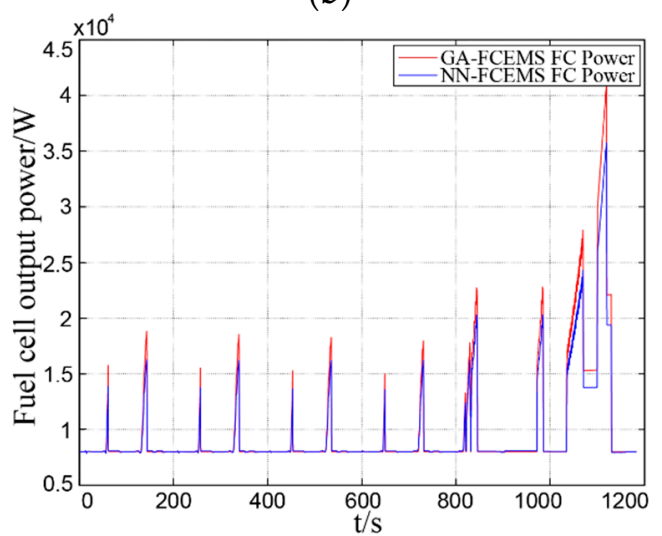

(d)

Figure 9. Comparison of actual fuel cell output power and neural network predicted value under UDDS/NEDC. (a) Test set data verification under UDDS; (b) Output power comparison between GA-FCEMS and NN-FCEMS under UDDS; (c) Test set data verification under NEDC; (d) Output power comparison between GA-FCEMS and NN-FCEMS under NEDC.

Although the genetic algorithm produces the best results, it is not suitable in all driving conditions because its input parameter velocity profile is not known in advance. As can be seen in Figure 10, the proposed strategy based on the artificial neural network trained by the results of the genetic algorithm optimized fuzzy controller executed offline determines a near-optimal power distribution between the fuel cell and the battery, indicating whether the battery should be charged or discharged. At the same time, the proposed artificial neural network uses existing data as experience to obtain a model containing certain laws, and uses the model to predict future data characteristics step by step. Therefore, the strategy is insensitive to the driving cycles as long as the training sample is large enough. That is, this strategy can be applied to various driving conditions. 


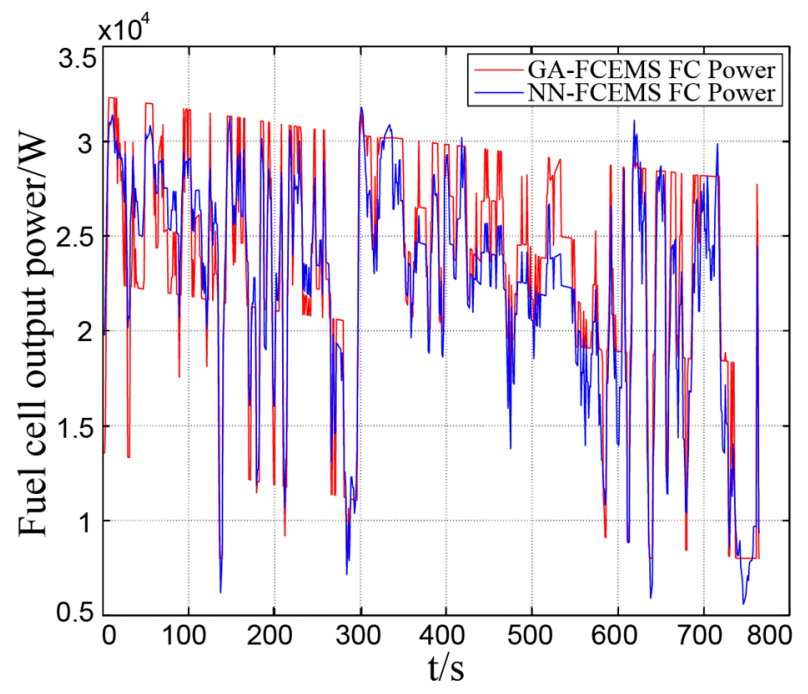

Figure 10. Comparison of actual fuel cell output power under HWFET between GA-FCEMS and NN-FCEMS.

Table 8. Prediction accuracy assessment of neural network using MAPE and RMSE.

\begin{tabular}{cccc}
\hline & UDDS & NEDC & HWFET \\
\hline MAPE $(\%)$ & 1.1154 & 2.3851 & 5.0749 \\
RMSE $\left(\times 10^{4}\right)$ & 0.2009 & 0.3085 & 0.3645 \\
\hline
\end{tabular}

Table 9. Prediction accuracy assessment of neural network using 10 -fold cross-validation.

\begin{tabular}{cccccccccccc}
\hline Iteration Number & $\mathbf{1}$ & $\mathbf{2}$ & $\mathbf{3}$ & $\mathbf{4}$ & $\mathbf{5}$ & $\mathbf{6}$ & $\mathbf{7}$ & $\mathbf{8}$ & $\mathbf{9}$ & $\mathbf{1 0}$ & Average \\
\hline$R^{2}$ in NEDC (\%) & 0.9456 & 0.9645 & 0.9720 & 0.9658 & 0.9470 & 0.9659 & 0.9733 & 0.9698 & 0.9726 & 0.9705 & 0.9647 \\
$R^{2}$ in UDDS (\%) & 0.8431 & 0.8527 & 0.9230 & 0.8908 & 0.8501 & 0.8870 & 0.8649 & 0.8545 & 0.8779 & 0.8906 & 0.8735 \\
\hline
\end{tabular}

Table 10. Results comparison between NN-FCEMS and GA-FCEMS per cycle under UDDS/NEDC/HWFET.

\begin{tabular}{|c|c|c|c|c|c|c|c|c|c|}
\hline \multirow[b]{2}{*}{ Cost $/ ¥$} & \multicolumn{3}{|c|}{ UDDS } & \multicolumn{3}{|c|}{ NEDC } & \multicolumn{3}{|c|}{ HWFET } \\
\hline & $\begin{array}{c}\text { NN- } \\
\text { FCEMS }\end{array}$ & $\begin{array}{l}\text { GA- } \\
\text { FCEMS }\end{array}$ & Difference & $\begin{array}{c}\text { NN- } \\
\text { FCEMS }\end{array}$ & $\begin{array}{c}\text { GA- } \\
\text { FCEMS }\end{array}$ & Difference & $\begin{array}{c}\text { NN- } \\
\text { FCEMS }\end{array}$ & $\begin{array}{c}\text { GA- } \\
\text { FCEMS }\end{array}$ & Difference \\
\hline Hydrogen & 18.2256 & 18.1629 & $0.35 \%$ & 11.2092 & 11.2700 & $-0.54 \%$ & 15.9268 & 14.6782 & $8.51 \%$ \\
\hline $\begin{array}{l}\text { FC degra- } \\
\text { dation }\end{array}$ & 5.5693 & 5.4991 & $1.28 \%$ & 0.8036 & 0.8744 & $-8.10 \%$ & 3.0701 & 3.4796 & $-11.77 \%$ \\
\hline Total & 23.7949 & 23.6620 & $0.56 \%$ & 12.0128 & 12.1444 & $-1.08 \%$ & 18.9969 & 18.1578 & $4.62 \%$ \\
\hline
\end{tabular}

\section{Conclusions}

In order to comprehensively optimize the economy and the health state of the fuel cell electric vehicle powertrain system, a novel energy management strategy incorporating an optimized fuzzy controller is proposed in this article based on the establishment of a system simulation model. The strategy uses genetic algorithms to optimize the fuzzy controller under three driving cycles, UDDS, NEDC and HWFET, with the SOH of the fuel cell and the equivalent hydrogen consumption of the powertrain as the optimization objectives. The neural network algorithm is then used for predictive control of the fuzzy controller for the onboard application. The simulation results show that, compared with the empirical fuzzy controller, the fuzzy controller optimized by genetic algorithm can effectively reduce the hydrogen consumption and power loss under different driving conditions, then slow down the reduction of the fuel cell SOH. Under different operating conditions, the total cost is reduced by up to $11 \%$, while the fuel cell SOH optimization is up to $4 \%$. In addition, the neural network predictive control strategy trained with the optimal output power 
data of the fuel cell under UDDS and NEDC cycles also performs well in HWFET cycles, and its predicted power is similar to that obtained by the genetic algorithm-optimized fuzzy controller in HWFET cycles, which is assessed using MAPE, RMSE and 10-fold cross-validation. Therefore, as long as the training samples are comprehensive enough, the control system can still allocate the power requirement to the fuel cell and the battery under multiple driving conditions in such a way that the hydrogen consumption and power loss are the lowest and the $\mathrm{SOH}$ decreases as slowly as possible. Eventually, the rule-based energy management strategy can be freed from the dependence on driving conditions. In the next stage, besides the genetic algorithm, other evolutionary algorithms for a minimal cost will be considered in our study to obtain an optimized solution for the fuzzy controller. Then, the extensiveness and universality of the training data sets need to be improved for predictive control.

Author Contributions: Conceptualization and methodology, X.H.; software, S.L.; validation, X.H. and S.L.; formal analysis, X.H. and K.S.; data curation, S.L.; writing—original draft preparation, X.H. and S.L.; writing - review and editing, X.H. and K.S.; project administration and funding acquisition, T.Z. and Y.G. All authors have read and agreed to the published version of the manuscript.

Funding: This research was funded by the National Key R\&D Program of China, grant number 2018YFB0104501 and the Natural Science Foundation of Shanghai (China), grant number 19ZR1460300.

Institutional Review Board Statement: Not applicable.

Informed Consent Statement: Not applicable.

Data Availability Statement: Not applicable.

Conflicts of Interest: The authors declare no conflict of interest.

\section{Nomenclature}

Acronyms
PEMFC
FCHEV
FCS
EMS
SOH
SOC
GA
BPNN
NN
EIS
PMP
FCEMS
GA-FCEMS
NN-FCEMS
RMSE
MAPE
RC
UDDS
NEDC
HWFET
Symbols and subscripts
$F_{f}$
$F_{w}$
$F_{j}$

Proton exchange membrane fuel cell

Fuel cell hybrid electric vehicle

Fuel cell system

Energy management strategy

State of health

State of charge

Genetic algorithm

Back propagation neural network

Neural network

Electrochemical impedance spectra

Pontryagin's minimum principle

Fuzzy control energy management strategy

Fuzzy control energy management strategy optimized

using genetic algorithm

Fuzzy control energy management strategy using neural

network for prediction

Root mean square error

Mean absolute percentage error

Resistor-capacitor

Urban Dynamometer Driving Schedule

New Europe Driving Cycle

Highway Fuel Economy Test Cycle

Rolling resistance

Wind resistance

Acceleration resistance 


\begin{tabular}{|c|c|}
\hline$F_{i}$ & Gradient resistance \\
\hline$m$ & Vehicle mass \\
\hline$g$ & Acceleration of gravity \\
\hline$f$ & Coefficient of rolling resistance \\
\hline$\alpha$ & Slope \\
\hline$C_{D}$ & Coefficient of air resistance \\
\hline$A$ & Front area \\
\hline$u$ & Vehicle speed \\
\hline$\delta$ & Correction coefficient of rotating mass \\
\hline$\eta_{T}$ & Efficiency of the transmission system \\
\hline$P_{f c}$ & Power of the fuel cell \\
\hline$M_{\mathrm{H}_{2}}$ & Molar mass of hydrogen \\
\hline$I_{f c}$ & Fuel cell stack current \\
\hline$n$ & Number of the fuel cells \\
\hline$F$ & Faraday constant \\
\hline$E_{\mathrm{H}_{2}}$ & Low heating value of the hydrogen \\
\hline$\eta_{f_{c}}$ & Fuel cell efficiency \\
\hline$I_{\text {bat }}$ & Battery output current \\
\hline$P_{\text {bat }}$ & Battery output power \\
\hline$U_{o c}$ & Open circuit voltage \\
\hline$R_{\text {bat }}$ & Battery internal resistance \\
\hline$C_{\text {cap }}$ & Battery capacity \\
\hline$m_{1}$ & Hydrogen consumption of the fuel cell \\
\hline$m_{2}$ & Equivalent hydrogen consumption of the battery \\
\hline$m\left(H_{2}\right)$ & Equivalent hydrogen consumption of the vehicle \\
\hline$\overline{\eta_{\text {dis }}}$ & Average efficiency of battery discharging \\
\hline$\overline{\eta_{\text {chg }}}$ & Average efficiency of battery charging \\
\hline$T_{M}^{\circ}$ & Motor torque \\
\hline$P_{M-r e q}$ & Motor required power \\
\hline$\eta_{M}$ & Efficiency of the motor \\
\hline$n_{M}$ & Motor speed \\
\hline$\delta_{T}$ & Power torque conversion coefficient \\
\hline$\delta_{P}$ & Torque power conversion coefficient \\
\hline $\mathrm{C}_{\text {per- } \mathrm{H}_{2}}$ & Cost of hydrogen consumption \\
\hline$C_{p e r-f c}$ & Cost of fuel cell degradation \\
\hline
\end{tabular}

\section{References}

1. Yue, M.; Jemei, S.; Zerhouni, N. Health-Conscious Energy Management for Fuel Cell Hybrid Electric Vehicles Based on PrognosticsEnabled Decision-Making. IEEE Trans. Veh. Technol. 2019, 68, 11483-11491. [CrossRef]

2. Mansour, C.; Salloum, N.; Francis, S.; Baroud, W. Adaptive Energy Management Strategy for a Hybrid Vehicle Using Energetic Macroscopic Representation. In Proceedings of the 2016 IEEE Vehicle Power and Propulsion Conference (VPPC), Hangzhou, China, 17-20 October 2016.

3. Sulaiman, N.; Hannan, M.A.; Mohamed, A.; Ker, P.J.; Majlan, E.H.; Daud, W.R.W. Optimization of energy management system for fuel-cell hybrid electric vehicles: Issues and recommendations. Appl. Energy 2018, 228, 2061-2079. [CrossRef]

4. Ravey, A.; Mohammadi, A.; Bouquain, D. Control strategy of fuel cell electric vehicle including degradation process. In Proceedings of the IECON 2015-41st Annual Conference of the IEEE Industrial Electronics Society, Yokohama, Japan, 9-12 November 2015.

5. Zheng, C.H.; Xu, G.Q.; Park, Y.I.; Lim, W.S.; Cha, S.W. Prolonging fuel cell stack lifetime based on Pontryagin's Minimum Principle in fuel cell hybrid vehicles and its economic influence evaluation. J. Power Source 2014, 248, 533-544. [CrossRef]

6. Tie, S.F.; Tan, C.W. A review of energy sources and energy management system in electric vehicles. Renew. Sustain. Energy Rev. 2013, 20, 82-102. [CrossRef]

7. Faivre, S.; Ravey, A.; Djerdir, A.; Bouquain, D. Degraded control strategy using state-of-health in fuel cell hybrid electric vehicles. In Proceedings of the 2013 IEEE Transportation Electrification Conference and Expo: Components, Systems, and Power Electronics-From Technology to Business and Public Policy, ITEC, Detroit, MI, USA, 16-19 June 2013.

8. Holmberg, K.; Erdemir, A. The impact of tribology on energy use and $\mathrm{CO}_{2}$ emission globally and in combustion engine and electric cars. Tribol. Int. 2019, 135, 389-396. [CrossRef]

9. Lü, X.; Qu, Y.; Wang, Y.; Qin, C.; Liu, G. A comprehensive review on hybrid power system for PEMFC-HEV: Issues and strategies. Energy Convers. Manag. 2018, 171, 1273-1291. [CrossRef] 
10. Wang, G.; Yu, Y.; Liu, H.; Gong, C.; Wen, S.; Wang, X.; Tu, Z. Progress on design and development of polymer electrolyte membrane fuel cell systems for vehicle applications: A review. Fuel Process. Technol. 2018, 179, 203-228. [CrossRef]

11. Wang, Y.; Chen, K.S.; Mishler, J.; Cho, S.C.; Adroher, X.C. A review of polymer electrolyte membrane fuel cells: Technology, applications, and needs on fundamental research. Appl. Energy 2011, 88, 981-1007. [CrossRef]

12. Kurz, T.; Hakenjos, A.; Krämer, J.; Zedda, M.; Agert, C. An impedance-based predictive control strategy for the state-of-health of PEM fuel cell stacks. J. Power Source 2008, 180, 742-747. [CrossRef]

13. Giner-Sanz, J.J.; Ortega, E.M.; Pérez-Herranz, V. Montecarlo based quantitative Kramers-Kronig test for PEMFC impedance spectrum validation. Int. J. Hydrogen Energy 2015, 40, 11279-11293. [CrossRef]

14. Meng, X.; Li, Q.; Zhang, G.; Wang, T.; Chen, W.; Cao, T. A dual-mode energy management strategy considering fuel cell degradation for energy consumption and fuel cell efficiency comprehensive optimization of hybrid vehicle. IEEE Access 2019, 7, 134475-134487. [CrossRef]

15. Li, H.; Ravey, A.; N’Diaye, A.; Djerdir, A. Equivalent consumption minimization strategy for fuel cell hybrid electric vehicle considering fuel cell degradation. In Proceedings of the 2017 IEEE Transportation and Electrification Conference and Expo, ITEC, Chicago, IL, USA, 22-24 June 2017.

16. Yue, M.; Jemei, S.; Zerhouni, N.; Gouriveau, R. Towards the Energy Management of a Fuel Cell/Battery Vehicle Considering Degradation. In Proceedings of the 2017 IEEE Vehicle Power and Propulsion Conference, VPPC, Belfort, France, 11-14 December 2017.

17. Wang, Y.; Liu, H.; Lu, C.; Zhou, B. PEM fuel cell health state assessment using a geometrical approach and mahalanobis distance. In Proceedings of the World Congress on Intelligent Control and Automation (WCICA), Guilin, China, 12-15 June 2016.

18. Ibrahim, M.; Jemei, S.; Wimmer, G.; Hissel, D. Nonlinear autoregressive neural network in an energy management strategy for battery/ultra-capacitor hybrid electrical vehicles. Electr. Power Syst. Res. 2016, 136, 262-269. [CrossRef]

19. $\mathrm{Xu}, \mathrm{L} . ; \mathrm{Li}$, J.; Ouyang, M. Energy flow modeling and real-time control design basing on mean values for maximizing driving mileage of a fuel cell bus. Int. J. Hydrogen Energy 2015, 40, 15052-15066. [CrossRef]

20. Meng, X.; Hao, D.; Wang, R.; Xu, Y.; Wei, Z.; Zhang, L. Research on the Energy Management Strategy of Range Extended Fuel Cell Electric Vehicle. In Proceedings of the 2020 IEEE 4th Information Technology, Networking, Electronic and Automation Control Conference (ITNEC), Chongqing, China, 12-14 June 2020.

21. Hemi, H.; Ghouili, J.; Cheriti, A. A real time energy management for electrical vehicle using combination of rule-based and ECMS. In Proceedings of the 2013 IEEE Electrical Power and Energy Conference (EPEC), Halifax, NX, Canada, 21-23 August 2013.

22. Erdinc, O.; Vural, B.; Uzunoglu, M. A wavelet-fuzzy logic based energy management strategy for a fuel cell/battery/ultracapacitor hybrid vehicular power system. J. Power Source 2009, 194, 369-380. [CrossRef]

23. Ravey, A.; Faivre, S.; Higel, C.; Harel, F.; Djerdir, A. Energy management of fuel cell electric vehicle with hydrid tanks. In Proceedings of the IECON Proceedings (Industrial Electronics Conference), Dallas, TX, USA, 29 October-1 November 2014.

24. Kim, M.; Jung, D.; Min, K. Hybrid thermostat strategy for enhancing fuel economy of series hybrid intracity bus. IEEE Trans. Veh. Technol. 2014, 63, 3569-3579. [CrossRef]

25. Liu, D.; Wang, Y.; Zhou, X.; Lv, Z. Extended range electric vehicle control strategy design and muti-objective optimization by genetic algorithm. In Proceedings of the Proceedings-2013 Chinese Automation Congress, CAC, Changsha, China, 7-8 November 2013.

26. Ming, L.; Ying, Y.; Liang, L.; Yao, L.; Zhou, W. Energy Management Strategy of a Plug-in Parallel Hybrid Electric Vehicle Using Fuzzy Control. Energy Procedia 2017, 105, 2660-2665. [CrossRef]

27. Shen, D.; Lim, C.C.; Shi, P. Fuzzy Model Based Control for Energy Management and Optimization in Fuel Cell Vehicles. IEEE Trans. Veh. Technol. 2020, 69, 14674-14688. [CrossRef]

28. Fares, D.; Chedid, R.; Karaki, S.; Jabr, R.; Panik, F.; Gabele, H.; Huang, Y. Optimal power allocation for a FCHV based on linear programming and PID controller. Int. J. Hydrogen Energy 2014, 39, 21724-21738. [CrossRef]

29. Larsson, V.; Johannesson, L.; Egardt, B. Analytic solutions to the dynamic programming subproblem in hybrid vehicle energy management. IEEE Trans. Veh. Technol. 2015, 64, 1458-1467. [CrossRef]

30. Odeim, F.; Roes, J.; Wülbeck, L.; Heinzel, A. Power management optimization of fuel cell/battery hybrid vehicles with experimental validation. J. Power Source 2014, 252, 333-343. [CrossRef]

31. Odeim, F.; Roes, J.; Heinzel, A. Power Management Optimization of a Fuel Cell/Battery/Supercapacitor Hybrid System for Transit Bus Applications. IEEE Trans. Veh. Technol. 2016, 65, 5783-5788. [CrossRef]

32. Shabbir, W.; Evangelou, S.A. Exclusive Operation Strategy for the Supervisory Control of Series Hybrid Electric Vehicles. IEEE Trans. Control Syst. Technol. 2016, 24, 2190-2198. [CrossRef]

33. Ribau, J.; Viegas, R.; Angelino, A.; Moutinho, A.; Silva, C. A new offline optimization approach for designing a fuel cell hybrid bus. Transp. Res. Part C Emerg. Technol. 2014, 42, 14-27. [CrossRef]

34. Hankache, W.; Caux, S.; Hissel, D.; Fadel, M. Genetic algorithm fuzzy logic energy management strategy for fuel cell hybrid vehicle. IFAC Proc. Vol. (IFAC-PaperOnline) 2009, 42, 137-142. [CrossRef]

35. Ahmadi, S.; Bathaee, S.M.T.; Hosseinpour, A.H. Improving fuel economy and performance of a fuel-cell hybrid electric vehicle (fuel-cell, battery, and ultra-capacitor) using optimized energy management strategy. Energy Convers. Manag. 2018, 160, 74-84. [CrossRef] 
36. Ryu, J.; Park, Y.; Sunwoo, M. Electric powertrain modeling of a fuel cell hybrid electric vehicle and development of a power distribution algorithm based on driving mode recognition. J. Power Source 2010, 195, 5735-5748. [CrossRef]

37. Wu, Y.; Zhang, Y.; Li, G.; Shen, J.; Chen, Z.; Liu, Y. A predictive energy management strategy for multi-mode plug-in hybrid electric vehicles based on multi neural networks. Energy 2020, 208, 118366. [CrossRef]

38. He, H.; Sun, C.; Zhang, X. A method for identification of driving patterns in hybrid electric vehicles based on a LVQ neural network. Energies 2012, 5, 3363-3380. [CrossRef]

39. Zhu, T.; Wills, R.G.A.; Lot, R.; Ruan, H.; Jiang, Z. Adaptive energy management of a battery-supercapacitor energy storage system for electric vehicles based on flexible perception and neural network fitting. Appl. Energy 2021, 292, 116932. [CrossRef]

40. Fletcher, T.; Thring, R.H.; Watkinson, M.; Staffell, I. Comparison of Fuel Consumption and Fuel Cell Degradation Using an Optimised Controller. ECS Trans. 2016, 71. [CrossRef]

41. Marx, N.; Hissel, D.; Gustin, F.; Boulon, L.; Agbossou, K. On the sizing and energy management of an hybrid multistack fuel cell-Battery system for automotive applications. Int. J. Hydrogen Energy 2017, 42, 1518-1526. [CrossRef]

42. Martel, F.; Kelouwani, S.; Dubé, Y.; Agbossou, K. Optimal economy-based battery degradation management dynamics for fuel-cell plug-in hybrid electric vehicles. J. Power Source 2015, 274, 367-381. [CrossRef]

43. Liu, C.; Liu, L. Optimal power source sizing of fuel cell hybrid vehicles based on Pontryagin's minimum principle. Int. J. Hydrogen Energy 2015, 40, 8454-8464. [CrossRef]

44. Song, K.; Chen, H.; Wen, P.; Zhang, T.; Zhang, B.; Zhang, T. A comprehensive evaluation framework to evaluate energy management strategies of fuel cell electric vehicles. Electrochim. Acta 2018, 292, 960-973. [CrossRef]

45. Song, K.; Wang, X.; Li, F.; Sorrentino, M.; Zheng, B. Pontryagin's minimum principle-based real-time energy management strategy for fuel cell hybrid electric vehicle considering both fuel economy and power source durability. Energy 2020, $205,118064$. [CrossRef]

46. Nejad, S.; Gladwin, D.T.; Stone, D.A. A systematic review of lumped-parameter equivalent circuit models for real-time estimation of lithium-ion battery states. J. Power Source 2016, 316, 183-196. [CrossRef]

47. Wang, X.; He, H.; Sun, F.; Zhang, J. Application study on the dynamic programming algorithm for energy management of plug-in hybrid electric vehicles. Energies 2015, 8, 3225-3244. [CrossRef]

48. Li, J.; Wang, Y.; Chen, J.; Zhang, X. Study on energy management strategy and dynamic modeling for auxiliary power units in range-extended electric vehicles. Appl. Energy 2017, 194, 363-375. [CrossRef]

49. Tribioli, L.; Cozzolino, R.; Chiappini, D.; Iora, P. Energy management of a plug-in fuel cell/battery hybrid vehicle with on-board fuel processing. Appl. Energy 2016, 184, 140-154. [CrossRef]

50. Han, X.; Lu, L.; Zheng, Y.; Feng, X.; Li, Z.; Li, J.; Ouyang, M. A review on the key issues of the lithium ion battery degradation among the whole life cycle. eTransportation 2019, 1, 100005. [CrossRef]

51. Song, K.; Li, F.; Hu, X.; He, L.; Niu, W.; Lu, S.; Zhang, T. Multi-mode energy management strategy for fuel cell electric vehicles based on driving pattern identification using learning vector quantization neural network algorithm. J. Power Source 2018, 389, 230-239. [CrossRef]

52. Han, X.; Li, F.; Zhang, T.; Zhang, T.; Song, K. Economic energy management strategy design and simulation for a dual-stack fuel cell electric vehicle. Int. J. Hydrogen Energy 2017, 42, 11584-11595. [CrossRef]

53. Xu, L.; Mueller, C.D.; Li, J.; Ouyang, M.; Hu, Z. Multi-objective component sizing based on optimal energy management strategy of fuel cell electric vehicles. Appl. Energy 2015, 157, 664-674. [CrossRef]

54. Zhang, C.; Shi, Q.; Cui, N.; Li, W. Particle swarm optimization for energy management fuzzy controller design in dual-source electric vehicle. In Proceedings of the PESC Record-IEEE Annual Power Electronics Specialists Conference, Orlando, FL, USA, 17-21 June 2007.

55. Liu, H.; Chen, J.; Wu, C.; Chen, H. Multi-objective optimization for energy management of fuel cell hybrid electric vehicles. In Proceedings of the Proceedings of the American Control Conference (ACC), Milwaukee, WI, USA, 27-29 June 2018.

56. Chen, Y.; Zhang, G. Exchange rates determination based on genetic algorithms using mendel's principles: Investigation and estimation under uncertainty. Inf. Fusion 2013, 14, 327-333. [CrossRef]

57. Amiri, M.; Esfahanian, M.; Hairi-Yazdi, M.R.; Esfahanian, V. Minimization of power losses in hybrid electric vehicles in view of the prolonging of battery life. J. Power Source 2009, 190, 372-379. [CrossRef]

58. China Hydrogen Alliance. China's Hydrogen Energy and Fuel Cell Industry White Paper; China Hydrogen Alliance: Beijing, China, 2019.

59. Dolatabadi, M.; Mehrabpour, M.; Esfandyari, M.; Alidadi, H.; Davoudi, M. Modeling of simultaneous adsorption of dye and metal ion by sawdust from aqueous solution using of ANN and ANFIS. Chemom. Intell. Lab. Syst. 2018, 181, 72-78. [CrossRef]

60. Bobyr, M.V.; Emelyanov, S.G. A nonlinear method of learning neuro-fuzzy models for dynamic control systems. Appl. Soft Comput. J. 2020, 88, 106030. [CrossRef]

61. Xiong, Z.; Cui, Y.; Liu, Z.; Zhao, Y.; Hu, M.; Hu, J. Evaluating explorative prediction power of machine learning algorithms for materials discovery using k-fold forward cross-validation. Comput. Mater. Sci. 2020, 171, 109203. [CrossRef]

62. Hong, J.; Wang, Z.; Chen, W.; Wang, L.Y.; Qu, C. Online joint-prediction of multi-forward-step battery SOC using LSTM neural networks and multiple linear regression for real-world electric vehicles. J. Energy Storage 2020, 30, 101459. [CrossRef] 